\title{
Contributions on vertebrate paleontology in Venezuela
}

\section{Preface}

\author{
Marcelo R. Sánchez-Villagra, Zürich \& Orangel A. Aguilera, Coro
}

Venezuela, located in the septentrional area of South America in the Caribbean, is considered one of the "megadiverse" countries in the world, belonging to the list of 15 countries with highest species diversity (RoDRÍGUEZ \& ROJAS-SUÁREZ 1999), including vertebrates of all kinds, many currently being described (e.g., LEW et al. 2006). This richness is in contrast with one of the poorest known vertebrate fossil records in the continent. This is regrettable, as Venezuela has been hypothesized to have been at critical geographical positions to understand biogeographic and evolutionary patterns at different times during the Phanerozoic (e.g., ITURRALDE-VINENT \& MACPHEE 1999; YounG \& MODY 2002). Venezuela is situated in tropical America, and the tropics have been hypothesized as being cradle and museum for evolution: centers of origin of vertebrate diversity and reservoirs of basal clades extinct in higher latitudes ( $\mathrm{J}_{\mathrm{A}-}$ BLONSKI et al. 2006). The Orinoco river is also a major reservoir of freshwater diversity and its past history must have been a fundamental factor in shaping the communities of organisms that inhabit the northern Neotropics. The total area of Venezuela is little over $900.000 \mathrm{~km}^{2}$, and from it a contribution to the understanding of the biochronology of South American vertebrates, so much biased towards the Southern cone, is expected.

The first step to study evolutionary patterns in deep time is describing the paleobiodiversity. In this collection of papers, we continue our ongoing efforts to study Venezuelan vertebrate paleontology by bringing into print descriptions and reviews of taxa from a geochronology sequences in different sedimentary basins and paleoenvironments (AGUILERA 2004, 2006; SÁNCHEZVILLAGRA \& CLACK 2004; SÁNCHEZ-VILLAGRA 2006). Besides the descriptions of the results of our own collecting efforts, we have organized the study of material in existing collections mostly in the cities of Coro, Uru-

Fig. 1. The classic Urumaco locality of "El Mamón", where many significant fossil vertebrates have been found and where some of the early oil exploration in the area was conducted. Photo courtesy of Fernando Acosta (Universidad Nacional Experimental Francisco de Miranda).

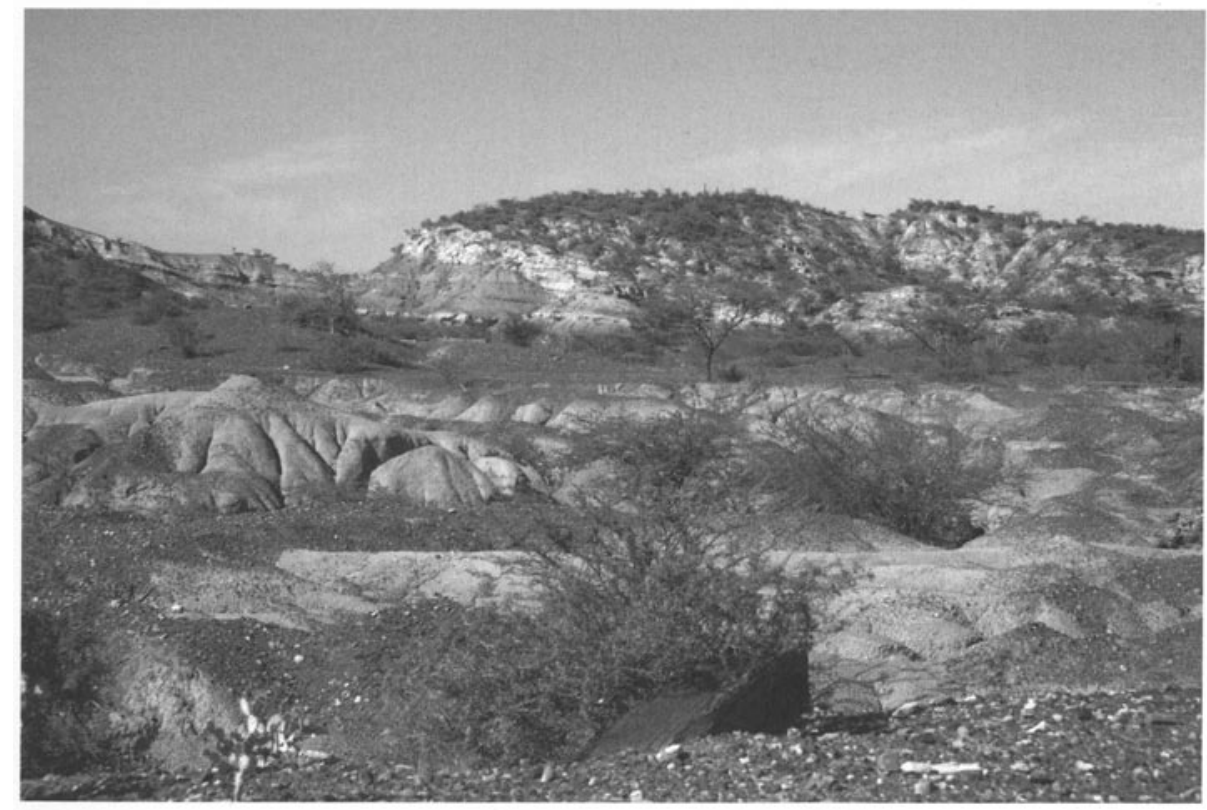

Addresses of the authors: Marcelo R. Sánchez-Villagra, Paläontologisches Institut und Museum, Universität Zürich, Karl SchmidStrasse 4, CH-8006 Zürich, Switzerland; e-mail <m.sanchez@pim.uzh.ch>. - Orangel A. Aguilera, Universidad Nacional Experimental Francisco de Miranda, Centro de Investigaciones en Ciencias Básicas, Complejo Docente Los Perozo, Carretera Variante Sur, Coro, 4101, Estado Falcón, Venezuela; e-mail <orangel.aguilera@gmail.com>. 
maco, Caracas, and Maracaibo. Collaborations with experts on different taxonomic groups have made this possible, and we are grateful to the invited authors for their excellent contributions.

We thank Michael Amler and Oliver Rauhut for the opportunity to publish contributions on this fauna in a single issue of this journal. We would like to especially thank our colleagues Alfredo Carlini and Ken Johnson for their great input in this phase of this project, and our colleagues in the field, Rodolfo Sánchez, Cathy Villalba, Roberto Lozsán, and Alfredo Zurita, for their hard work and comradeship. We also thank the financial support of the University of Zürich, of the "Fonds zur Förderung des akademischen Nachwuchses (FAN) des Zürcher Universitätsvereins (ZUNIV)" for supporting T. Scheyer and the work in the Mesozoic and of the Universidad Nacional Experimental Francisco de Miranda, which made this work possible.

\section{References}

AgUilera, O. 2004. Tesoros paleontológicos de Venezuela: Urumaco, Patrimonio Natural de la Humanidad. - 147 p., Caracas (Editorial Arte).
AgUILERA, O. 2006. Tesoros Paleontológicos de Venezuela: El Cuaternario del Nordeste del Estado Falcón. - 120 p., Caracas (Editorial Arte).

IturRalde-Vinent, M.A. \& MaCPheE, R.D.E. 1999. Paleogeography of the Caribbean region: Implications for Cenozoic biogeography. - Bulletin of the American Museum of Natural History 238: $1-95$.

JABLONSKI, D.; RoY, K. \& VAlEnTINE, JW. 2006. Out of the Tropics: Evolutionary dynamics of the latitudinal diversity gradient. Science 314: 102-106.

Lew, D.; Pérez-Hernández, R. \& Ventura, J. 2006. Two new species of Philander (Didelphimorphia, Didelphidae) from northern South America. - Journal of Mammalogy 87: 224-237.

RODRÍGUEZ, J.P. \& RoJAS-SUÁREZ, F. 1999. Libro Rojo de la Fauna Venezolana. $2^{\text {nd }}$ ed. -472 p., Caracas (Provita \& Fundación Polar).

SÁnChEZ-VILlaGRA, M.R. \& ClACK, J.A., eds., 2004. Fossils of the Castillo Formation, Venezuela: Contributions on Neotropical Palaeontology. - Special Papers in Palaeontology 71: 1-112.

SÁnCHEZ-Villagra, M.R. \& AGUilerA, O. 2006. Neogene vertebrates from Urumaco, Falcón State, Venezuela: diversity and significance. - Journal of Systematic Palaeontology 4:213220.

YounG, G.C. \& MoOdy, J.M. 2002. A Middle-Late Devonian fish fauna from the Sierra de Perijá, western Venezuela, South America. - Mitteilungen des Museums für Naturkunde Berlin, Geowissenschaftliche Reihe 5: 155-206. 